\title{
Antibacterial Efficacy of Carica Papaya Leaves and Stem Bark Extracts on Clinical Isolates of Methicillin Resistant
} Staphylococcus Aureus (Mrsa)

\section{Umar $\mathbf{A}^{1}$, Nas FS ${ }^{2}$ and Ali $\mathbf{M}^{3 *}$}

${ }^{1}$ Biological Science Unit, Ahmadu Bello University, School of Basic and Remedial studies Funtua, Nigeria

2Department of Biology, Bayero University, Kano

${ }^{3}$ Department of Microbiology, Kano University of Science and Technology, Wudil

\section{Research Article}

Volume 2 Issue 2

Received Date: April 10, 2018

Published Date: May 04, 2018

*Corresponding author: Muhammad Ali, Department of Microbiology, Kano University of Science and Technology, Wudil Kano, Nigeria, Email: alimuhd4real@gmail.com

\section{Abstract}

The research was conducted to determine phytochemicals composition and antibacterial efficacy of leaves and stem bark extracts of Carica papaya on clinical isolates of MRSA. The preliminary phytochemical screening of the extracts revealed the presence of alkaloid, reducing sugar, steroid, terpenoids, phenol, anthraquinone, protein and amino acid, tannin, saponin and flavonoids in the leaves extracts while alkaloid, saponin and flavonoids were found in the stem bark extract. Using agar well diffusion method for determination of antibacterial activity of the extracts, the results revealed that the leaves extract demonstrated antibacterial effects on 5 out of 6 isolates tested with higher activity in ethanolic extracts when compared to aqueous extracts. All the 6 isolates were resistant to both aqueous and ethanolic extracts of the stem bark. Statistical analysis of the results showed that isolate number 6 is the most susceptible covering average zone of inhibition of $16.37 \mathrm{~mm}$ followed by isolate 4 with $12.75 \mathrm{~mm}$, least zone of inhibition was recorded in isolate 5 with 6.00 $\mathrm{mm}$ which found resistant to the extracts. The MIC and MBC of the leaves extracts ranges from $25-200 \mathrm{mg} / \mathrm{ml}$. There is significant different on the susceptibility of the isolates against the extracts used at $\mathrm{p}<0.05$. Based on the findings of this research, the ethno-botanical use of the plant is justified.

Keywords: Antibacterial Activity; Methicillin-Resistant Staphylococcus aureus; Carica papaya, Phytochemical 


\section{Bioequivalence \& Bioavailability International Journal}

Abbreviations: MIC: Minimum Inhibitory Concentration; MBC: Minimum Bactericidal Concentration; MRSA: Methicillin Resistant Staphylococcus aureus; DMSO: Dimethylsulphoxide.

\section{Introduction}

In history, plants have played a major role in the production of biological compounds for the formation of drugs. Their role may either become a base for the development of medicine, a natural blue print for the development of new drugs or a phyto-medicine to be used for the treatment of diseases [1]. Even the World Health Organization (WHO) supports the use of medicinal plants, provided it is proven to be efficacious and safe [2]. The scientific search for new drugs from natural products remains a serious task for scientists worldwide. It is a fact that a large segment of the population in tropical countries rely on traditional medicines for their health needs [3]. Over $80 \%$ of population in the developing world makes use of medicinal plants extracts to provide health [4]. The searches for new compounds with antimicrobial activity from plants have been the subject for intense research in recent years [1]. This is due to the fact that plants are widely used in folk medicine to combat various diseases in human caused by pathogenic organisms. For this reason, many researchers are aiming to scientifically prove the use of plant extracts as an effective means of controlling infections and body malfunctions [5].

Methicillin-resistant Staphylococcus aureus (MRSA) is a strain of Staphylococcus aureus that is resistant to the antibacterial activity of methicillin and other related antibiotics of the penicillin class [6]. It belongs to the large group of bacteria known as Staphylococci, often referred to as Staph. About 25\%-30\% of all people have Staph within the nose, but it normally does not cause an infection. In contrast, only about $1 \%$ of the populations have MRSA [7]. Infections with MRSA are most common in hospitals and other institutional health-care settings, such as nursing homes, where they tend to affect older people, those who are very ill, and people with a weakened immune system [8].

Carica papaya L. belongs to the family of Caricaceae, and several species of Caricaceae have been used as a remedy against a variety of diseases [9]. Carica papaya $L$. is commonly called pawpaw (English), Gwanda (Hausa), Ibebe (Yoruba) or Okoegbe (Igbo) [10]. It is a monosexual plant of Central American origin [10]. Besides the fruit been edible, it has been reported that the roots and the leaves have been used as antihelminthes and for the treatment of infections of bacterial origin [11]. Papaya leave extracts have phenolic compound and caffeic acid [12]. Carica papaya plant produce natural compound in leaf and bark as well as twig tissues that poses both highly anti-tumor and pesticide properties [13]. The objective of the study is to determine the antibacterial activity and phytochemical constituents of Carica papaya extracts against clinical isolates of Methicillin Resistant Staphylococcus aureus MRSA.

\section{Materials and Methods}

\section{Ethical Approval}

Ethical approval (issue number HMB/GEN/488/VOL. 1) was obtained from the Murtala Mohammed Specialists Hospital (MMSH), Kano based on the consent of the Hospitals Ethical Committees.

\section{Experimental Microorganisms}

The experimental organisms (six different isolates of Methicillin Resistant Staphylococcus aureus) were isolated from clinical samples of high virginal swab, wounds and skin of patients from hospital patients presenting symptoms of $S$. aureus-associated diseases attending Murtala Mohammed Specialists Hospital Kano, Nigeria. The isolates were identified by standard method [14]. The pure culture of the confirmed isolates were preserved on Nutrient agar slants, labeled, transported to Microbiology Laboratory of Kano State University of Science and Technology Wudil and stored in refrigerator at $4^{0} \mathrm{C}$ for subsequent tests.

\section{Collection of Plant Materials}

Fresh green leaves and stem bark of Carica papaya were collected from Biological garden of Ahmadu Bello University School of Basic and Remedial Studies Funtua. The plant materials were carried to Herbarium in the Department of Biological Sciences, Ahmadu Bello University Zaria, Nigeria where they were authenticated. A voucher number was issued as 307 for future reference. The plant materials were washed thoroughly 5 times in sterile distilled water. Then air-dried under shade at room temperature for 14 days and pulverized to finely powdered form using pestle and mortar under laboratory condition as described by Ali, et al. [15].

\section{Preparation of Extracts}

The crude extracts from the stem bark and leaves of Carica papaya were prepared according to the method proposed by Alabi, et al. [16]. Fifty grams of powdered 
sample of each plant materials were extracted exhaustively (cold maceration) using distilled water and ethanol for 7 seven days. The extracts were filtered using Whatman No. 2 filter paper and concentrated at reduced pressure to afford the various crude extracts of the plants samples. The samples were kept in the refrigerator at $5^{\circ} \mathrm{C}$ until use.

\section{Phytochemical Screening}

The extracts were subjected to various phytochemical tests to identify the phytochemical constituents present using standard methods as described by Sofowora and Trease and Evans $[3,17]$. Phytochemical screening was performed to test for alkaloids, saponin, phenol, flavonoids, Protein and amino acid, reducing sugar, tannin, anthraquinone steroid and terpenoid.

\section{Determination of Antibacterial Activity of the Extracts}

Antibacterial activity of the aqueous and ethanolic extracts of the leaf and stem bark of Carica papaya using agar well diffusion method as described by Aida, et al. [18] was adopted to assess the antibacterial activity of the extracts against MRSA pathogens. The crude extracts were further diluted using $10 \%$ DMSO at the concentrations of $400 \mathrm{mg} / \mathrm{ml}, 300 \mathrm{mg} / \mathrm{ml}, 200 \mathrm{mg} / \mathrm{ml}$, and $100 \mathrm{mg} / \mathrm{ml}$. For the test, Muller-Hinton agar plates were swabbed with standard test isolates ( 0.5 McFarland), five wells were made on the surface of the agar using $6 \mathrm{~mm}$ sterile steel borer and the wells $(6 \mathrm{~mm})$ were filled with different concentration $(400,300,200$ and $100 \mathrm{mg} / \mathrm{ml}$ ) of $0.1 \mathrm{ml}$ of the extracts. The fifth well was filled with $200 \mathrm{mg} / \mathrm{ml}$ of Tetracycline as positive control. The cultures were incubated at $37^{\circ} \mathrm{C}$ for 24 hours. The antibacterial potential of test extracts were determined on the basis of diameter of zone of inhibition around the wells as described by Sumitra and Sharma [19].

\section{Determination of MIC and MBC}

The minimum inhibitory concentration (MIC) was determined using broth dilution method [20]. Concentrations of extracts dilutions were prepared using tubes containing $2 \mathrm{ml}$ of double strength Nutrient broth. The tubes were inoculated with the suspension of 0.1 standardized inocula ( 0.5 McFarland standard) and incubated at $37^{\circ} \mathrm{C}$ for $24 \mathrm{~h}$. MICs were recorded as the lowest concentration of extract showing no visible growth in the broth. The minimum bactericidal concentration (MBC) was however, determined by aseptically inoculating aliquots of culture from all MIC tubes without growth on sterile Mueller Hinton agar plates and incubating at $37^{\circ} \mathrm{C}$ for 24 hours. MBCs were recorded as the lowest concentration of extracts showing no bacterial growth [19].

\section{Statistical Analysis}

The data obtained from zones of inhibition produced by the isolates against the extracts used were analyzed using One-Way ANOVAs using statistical program SPSS 21.0 (Statistical Package for the Social Sciences). Significance level for the differences was set at $\mathrm{p}<0.05$.

\section{Results}

\section{Phytochemical Screening}

The phytochemical screening of the active phytochemical constituents of the extracts is presented in Table 1. Leaf extract contain alkaloids, saponin, phenol, flavonoids, Protein and amino acid, reducing sugar, anthraquinone steroid and terpenoid except Tannin, while stem extract contain only three phytochemicals Alkaloid, Saponin and Flavonoids. The result showed that Carica papaya leaves extract contain more phytochemicals than the stem bark extract.

\begin{tabular}{|c|c|c|c|}
\hline S/N & Phytochemicals & Leaf extract & Stem bark extract \\
\hline 1 & Alkaloid & + & + \\
\hline 2 & Saponin & + & + \\
\hline 3 & Phenol & + & + \\
\hline 4 & Flavonoid & + & - \\
\hline 5 & Protein and amino acid & - & - \\
\hline 6 & Tannin & + & - \\
\hline 7 & Reducing sugar & + & - \\
\hline 8 & Anthraquinone & + & - \\
\hline 9 & Steroid & + & - \\
\hline 10 & Terpenoid & & \\
\hline
\end{tabular}

Key: + = Presence of phytochemical, - = Absence of phytochemical.

Table 1: Phytochemical constituents of leaves and stem of Carica papaya 


\section{Bioequivalence \& Bioavailability International Journal}

\section{Antibacterial Activity of the Extracts}

The antibacterial activity of the plant leaves and stem bark aqueous and ethanolic extracts against the isolates is presented in Table 2. The result showed that highest antibacterial activity was demonstrated against isolate 6 with zone of inhibition of $20.00 \mathrm{~mm}$ at $400 \mathrm{mg} / \mathrm{ml}$ while no zone of inhibition was shown by isolate 5 at both concentration of the extract. Zone of inhibition shown by control $(200 \mathrm{mg} / \mathrm{ml}$ Gentamicin), ranges from 06.00 $21.00 \mathrm{~mm}$.

\begin{tabular}{|c|c|c|c|c|c|c|c|}
\hline \multicolumn{8}{|c|}{ Isolates/zone of inhibition } \\
\hline Extract & Conc.(mg/ml) & Isol. 1 & Isol. 2 & Isol. 3 & Isol. 4 & Isol. 5 & Isol. 6 \\
\hline \multirow[t]{4}{*}{ ALE } & 100 & $11^{\mathrm{b}}$ & $09 \mathrm{a}$ & $11^{\mathrm{b}}$ & $11^{\mathrm{b}}$ & $06^{\mathrm{a}}$ & $13^{\mathrm{b}}$ \\
\hline & 200 & $11^{\mathrm{b}}$ & $12^{\mathrm{b}}$ & $13^{b}$ & $11^{\mathrm{b}}$ & $06^{\mathrm{a}}$ & $13^{\mathrm{b}}$ \\
\hline & 300 & $12^{\mathrm{b}}$ & $13^{\mathrm{b}}$ & $13^{b}$ & $15^{b}$ & $06^{\mathrm{a}}$ & $19^{c}$ \\
\hline & 400 & $15^{b}$ & $13^{\mathrm{b}}$ & $17 \mathrm{~b}$ & $16^{\mathrm{b}}$ & $06^{\mathrm{a}}$ & $20^{c}$ \\
\hline \multirow[t]{4}{*}{ ELE } & 100 & $06^{\mathrm{a}}$ & $06^{\mathrm{a}}$ & $06^{\mathrm{a}}$ & $11^{\mathrm{b}}$ & $06^{\mathrm{a}}$ & $10^{\mathrm{b}}$ \\
\hline & 200 & $08^{a}$ & $10^{\mathrm{b}}$ & 09a & $12^{\mathrm{b}}$ & $06^{\mathrm{a}}$ & $15^{b}$ \\
\hline & 300 & $10^{\mathrm{b}}$ & $12^{\mathrm{b}}$ & $12^{\mathrm{b}}$ & $13^{\mathrm{b}}$ & $06^{\mathrm{a}}$ & $17^{\mathrm{b}}$ \\
\hline & 400 & $12^{\mathrm{b}}$ & $12^{\mathrm{b}}$ & $14^{\mathrm{b}}$ & $13^{\mathrm{b}}$ & $06^{\mathrm{a}}$ & $18^{\mathrm{c}}$ \\
\hline \multirow[t]{4}{*}{ ASE } & 100 & $06^{\mathrm{a}}$ & $06^{\mathrm{a}}$ & $06^{\mathrm{a}}$ & $06^{\mathrm{a}}$ & $06^{\mathrm{a}}$ & $06^{\mathrm{a}}$ \\
\hline & 200 & $06^{\mathrm{a}}$ & $06^{\mathrm{a}}$ & $06^{\mathrm{a}}$ & $06^{\mathrm{a}}$ & $06^{\mathrm{a}}$ & $06^{\mathrm{a}}$ \\
\hline & 300 & $06^{\mathrm{a}}$ & $06^{\mathrm{a}}$ & $06^{\mathrm{a}}$ & $06^{\mathrm{a}}$ & $06^{\mathrm{a}}$ & $06^{\mathrm{a}}$ \\
\hline & 400 & $06^{\mathrm{a}}$ & $06^{\mathrm{a}}$ & $06^{\mathrm{a}}$ & $06^{\mathrm{a}}$ & $06^{\mathrm{a}}$ & $06^{\mathrm{a}}$ \\
\hline \multirow[t]{4}{*}{ ESE } & 100 & $06^{\mathrm{a}}$ & $06^{\mathrm{a}}$ & $06^{\mathrm{a}}$ & $06^{\mathrm{a}}$ & $06^{\mathrm{a}}$ & $06^{\mathrm{a}}$ \\
\hline & 200 & $06^{\mathrm{a}}$ & $06^{\mathrm{a}}$ & $06^{\mathrm{a}}$ & $06^{\mathrm{a}}$ & $06^{\mathrm{a}}$ & $06^{\mathrm{a}}$ \\
\hline & 300 & $06^{\mathrm{a}}$ & $06^{\mathrm{a}}$ & $06^{\mathrm{a}}$ & $06^{\mathrm{a}}$ & $06^{\mathrm{a}}$ & $06^{\mathrm{a}}$ \\
\hline & 400 & $06^{a}$ & $06^{a}$ & $06^{\mathrm{a}}$ & $06^{\mathrm{a}}$ & $06^{a}$ & $06^{a}$ \\
\hline Control & 200 & 18 & 6 & 20 & 18 & 6 & 21 \\
\hline
\end{tabular}

Key: $\mathrm{ALE}=$ Aqueous leaves extract $; \mathrm{ELE}=$ Ethanol leaves extract; ASE $=$ Aqueous stem bark extract; ESE $=$ Ethanol stem bark extract

Table 2: Antibacterial activity of the extracts.

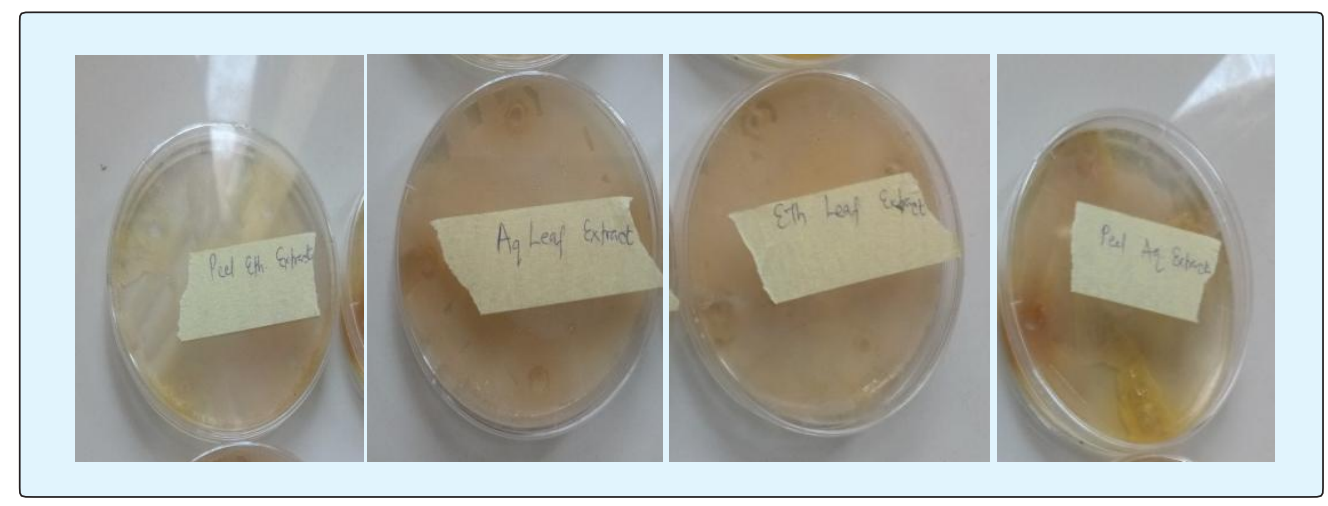

\section{Minimum Inhibitory Concentration (MIC) and Minimum Bactericidal Concentration (MBC) of the Extracts}

Minimum inhibitory concentration of aqueous and ethanolic leaves extracts is represented in Table 3 which shows dilutions of various concentrations of the leaf extract of Carica papaya against test isolates. Lower MIC was recorded in isolate 4 and $6(25 \mathrm{mg} / \mathrm{ml})$ while highest MIC was found to be $200 \mathrm{mg} / \mathrm{ml}$. Isolate 5 was found to be resistant to the extracts. The results indicated that both aqueous and ethanolic leaf extract of the plant can kill some test isolates (MBC) at concentration of 25 $200 \mathrm{mg} / \mathrm{ml}$ while not found in some isolates. 


\section{Bioequivalence \& Bioavailability International Journal}

\begin{tabular}{|c|c|c|c|c|c|c|}
\hline \multicolumn{7}{|c|}{ Isolates/MIC/MBC (mg/ml) } \\
\hline Extracts & Isolate 1 & Isolate 2 & Isolate 3 & Isolate 4 & Isolate 5 & Isolate 6 \\
\hline ALE & $200 / \mathrm{NF}$ & $200 / 200$ & $200 / \mathrm{NF}$ & $50 / 50$ & $\mathrm{NF} / \mathrm{NF}$ & $50 / 50$ \\
\hline ELE & $50 / 50$ & $100 / 100$ & $50 / 100$ & $25 / 50$ & $200 / \mathrm{NF}$ & $25 / 25$ \\
\hline
\end{tabular}

$\mathrm{NF}=$ Not found; ALE $=$ Aqueous leaves extract; $\mathrm{ELE}=\mathrm{Ethanol}$ leaves extract.

Table 3: Minimum inhibitory concentration (MIC) and minimum bactericidal concentration (MBC) of the extracts.

\section{Discussion}

The result for phytochemical screening of the leaves and stem bark of $C$. papaya showed that it contained some phytochemical compounds which possess good antimicrobial properties on the test clinical isolates used in this study. The phytochemical analysis of the plant showed the presence of Anthraquinones, phenols, glycoside, amino-acid, terpenoid, reducing sugar, Saponin, Tannin, Alkaloids and Flavonoids. This finding can be attested to the work of Sikanda et al. [21] who also reported similar finding and also stated the effect of these phytochemical as a good antimicrobial agent on different test organism. Doughari, et al. [10] reported the antibacterial effect of the extract of C. papaya on various bacterial isolates including Staphylococcus aureus, Salmonella typhi and Bacillus cereus. Although the mechanism of action of this extract is not understood, it has been proposed that its action against the bacteria and fungi may be due to the inhibition of cell wall formation in the cell resulting in a leakage of cytoplasmic constituents by the bioactive components of the extract $[22,23]$.

In addition, bioactive substances have been reported to confer resistance to plants against bacteria, fungi and pests and therefore explain the demonstration of antibacterial activity by the plant extracts used in this study [24]. In these regard, Aravind, et al. [25] reported that the many benefits of papaya, are due to the high content of Vitamins A, B and C, proteolytic enzymes like papain and chymopapain that have antiviral, antifungal and antibacterial properties while phytochemical compounds such as tannin coagulate the wall proteins, saponins facilitated the entry of toxic material or leakage of vital constituents from the cell [26].

Flavonoids inhibit the activity of enzymes by forming complexes with bacterial cell walls, extracellular and soluble proteins, more lipophilic flavonoids disrupt cell wall integrity or microbial membranes at low concentrations $[27,28]$. The existence of Saponin supports the fact that pawpaw has cytotoxic effect such as permealization of the intestine as Saponins are cytotoxic [29]. Alkaloids are the most efficient therapeutically influential plant substance. Pure natural and synthetic derivatives of alkaloids are used as a basic medical agent because of their analgesic, antispasmodic and antibacterial properties [30]. The presence of Alkaloid in the Carica papaya extracts shows that this plant can be an effective anti-malaria agent since alkaloid consists of quinine, which is anti-malaria [31]. Marchese and Shito and Poole reported the sensitivity of the microbial strains to both the plant extracts and to synthetic antibiotics, and observed that that the plant extracts compete favorably with the drugs and can be used as an alternative to the antibiotics as the zones of inhibition shown were very comparable and the extracts have lesser side effects which are often associated with the use of antibiotics. Also, the issue of resistance to these extracts cannot arise as is found with antibiotics [32-34].

The present study showed that the leaves of C. papaya possess antimicrobial potential against MRSA. In line with the present finding, several other studies have reported $C$. papaya leaves have antimicrobial potentials and have significant antibacterial activity in various extracts from different tree's parts [35-37]. The antibacterial activity of crude extracts used in this study shows that, leaf extract demonstrated higher antibacterial activity than the stem extract. The ethanolic leaf extract had highest zone of inhibition of $20 \mathrm{~mm}$ at $400 \mathrm{mg} / \mathrm{ml}$ in isolate number 6 . However, all isolate are resistant to ethanolic and aqueous extract of the stem. This is attributed to more phytochemical constituents in leaf compared to stem (Table 1). The results of this study also demonstrated that the organic extracts were more effective than aqueous extracts. This may be due to the better solubility of the active components in the organic solvent. The better efficacy of the ethanol extract as against the aqueous extract may be because different solvents have different polarities, hence different degrees of solubility for the various phytoconstituents $[10,38]$. The result of this study supported that of Yahaya, et al. [39] who found the aqueous and ethanol extract of Carica papaya leaves active against $E$. coli, $S$. typhi, $P$. aeruginosa and Staphylococcus aureus with higher activity in ethanol extract than aqueous extract.

From the results of MIC determination (Table 3), the minimum inhibitory concentration showed that a 


\section{Bioequivalence \& Bioavailability International Journal}

concentration of $25-200 \mathrm{mg} / \mathrm{ml}$, the leaf extract can inhibit the growth of the tested isolates. However, isolate 5 is resistant to both ethanolic and aqueous extract. The result of this study showed that organic extracts has lower MIC value for the tested isolates compared to aqueous extracts. These findings is in conformity with that of Ohue and Momoh, in which the antibacterial activity on different solvent extracts of Carica papaya leaf on some bacteria showed that the ethanolic extract has lower value $(28 \mathrm{mg} / \mathrm{ml})$ than aqueous extract $(30 \mathrm{mg} / \mathrm{ml})$ [40].

\section{Conclusion}

According to this study, ethanol extracts demonstrated a higher activity than the aqueous extracts in both extracts. The better efficacy of the ethanol extract as against the aqueous extract may be because different solvents have different polarities, hence different degrees of solubility for the various phytoconstituents. It was also found that leaves extracts of the plant possessed higher antibacterial efficacy when compared to stem bark extracts. Phytochemical screening of the extracts showed the presence of anthraquinone, phenols, glycoside, and amino-acid, terpenoid, reducing sugar, Saponin, alkaloids and flavonoids. The phytochemicals are responsible for the antibacterial activity of the extracts.

\section{Acknowledgement}

The authors wish to acknowledge the staff of Microbiology Department of Murtala Muhammad Specialist hospital Kano for isolates provision. Thanks to Microbiology Department, Kano University of Science and Technology Wudil, Kano for use of Laboratory facilities.

\section{References}

1. Iwu M (1993) Handbook of African Medical Plants. CRC Press, Boca Raton 48(1): 64.

2. World Health Organization/WHO (1995) The World Health Report. Bridging the gap. WHO, Geneva : 118.

3. Sofowora A (1993) Medicinal Plants and Traditional Medicine in Africa. $2^{\text {nd }}$ edition; Spectrum Books Ltd, Ibadan, Nigeria: 289.

4. WHO (2002) Use of antimicrobials outside human medicine and result and antimicrobial resistance in humans. World Health Organization Archieved from the Original on 13 May, 2004.
5. Burkill HM (1985) The Useful Plants of Tropical Africa, $2^{\text {nd }}$ (Edn.), Royal Botanical Garden: Kew Vol. 1,: 389.

6. Que YA, Moreillon P (2009) Staphylococcus aureus (including toxic shock). In: Mandell GL, Bennett JE, Dolin R, eds. Principles and Practice of Infectious Diseases. 7th Ed. Philadelphia, Pa: Elsevier Churchill Livingstone 195: 2543-2578.

7. Davis KA, Stewart JJ, Crouch HK, Florez CE, Hospenthal DR (2007) Methicillin-resistant Staphylococcus aureus (MRSA) nares colonization at hospital admission and its effect on subsequent MRSA infection. Clin Infect Dis 39(6): 776-782.

8. Blot S, Vandewounde K, Hoste E, Colardyn F (2002) Outcome and attributable mortality in critically ill patients with bacteraemias involving methicillinresistant Staphylococcus aureus. Arch Intern Med 162(19): 2229-2235.

9. Mello VJ, Gomes MT, Lemos FO, Delfino JL, Andrade SP, et al. (2008) The gastric ulcer protective and healing role of cysteine proteinases from Carica candamarcensis. Phytomedicine 15(4): 237-244.

10. Doughari JH, El Mahmood AM, Manzara S (2007) Studies on the antibacterial activities of root extract of Carica papaya L. Afri J Microbiol Res 037-041.

11. Fajimi AK, Taiwo AA, Ayodeji H, Adebowale EA, Ogundola FI (2001) Therapeutic trials on gastrointestinal helminthes parasites of goat busing pawpaw seeds as a drench. Proceeding of the International conference on sustainable crop, Livestock production for improved livelihood and Natural Resource Management, West Africa. International Institute of Tropical Agriculture (IITA).

12. Ayoola PB, Adeyeye A (2010) Phytochemical and nutrient evaluation of Carica papaya (pawpaw) leaves. IJRRAS 5(3).

13. Nirosha N, Mangalanayaki R (2013) Antibacterial Activity of Leaves and Stem Extract of Carica papaya L. Inter J Adv Pharmacy Bio Chem 2(3): 473-476.

14. Holt JG, Krieg NR, Sneath PA, Stanley JT, Williams ST (1994) Bergey's manual of systematic bacteriology, 9th edition. Williams \& Wilkins Co. Baltimore, Maryland: 786. 


\section{Bioequivalence \& Bioavailability International Journal}

15. Ali M, Yahaya A, Zage AU, Yusuf ZM (2017) In-vitro Antibacterial Activity and Phytochemical Screening of Psidium guajava on Some Enteric Bacterial Isolates of Public Health Importance. Journal of Advances in Medical and Pharmaceutical Sciences 12(3): 1-7.

16. Alabi OA, Haruna MT, Anokwuru CP, Jegede T, Abia H, et al. (2012) Comparative studies on antimicrobial properties of extracts of fresh and dried leaves of Carica papaya (L) on clinical bacterial and fiungal isolates. Advances in Applied Science Research 3(5): 3107-3114.

17. Trease GE and Evans WC (1989) Pharmacognosy, 13th edition; ELBS Oxford University Press, London, UK: 245-263.

18. Aida P, Rosa V, Blamea F, Tomas A, and Salvador C (2001) Paraguyan plants used in traditional medicine, Short communication. Journal of Ethnopharmocology 16: 93-98.

19. Sumitra S and Sharma SK (2006) The in-vitro antibacterial efficiency of essential oil and root extract of Coriandrum sativum Linn. Journal of Agricultural Biological Research 22: 144-149.

20. NCCLS (2000) Methods for Dilution Antimicrobial Susceptibility Tests for Bacteria That Grow Aerobically. Approved Standard Fifth Edition. NCCLS Document M7-A5, NCCLS: Wayne, PA, USA.

21. Sikandar KS, Tasveer ZB, Kanwal N, Syed AG, Shahama UK (2013) Qualitative phytochemical screening and antifungal activity of Carica papaya leaf extract against human and plant pathogenic fungi. Int Res J Pharm 4(7).

22. Bais HP, Walker TS, Schweizer HP, Vivanco, JM (2002) Plant Phy Biochem 40: 983-995.

23. Hassan SW, Umar RA, Ladan MJ, Nyemike P, Wasagu RSU, et al. (2007) Nutritive Value, Phytochemical and Antifungal Properties of Pergularia tomentosa L. (Asclepiadaceae). International Journal of Pharmacology 3(4): 334-340.

24. Srinivasan D, Perumalasamy LP and Nathan ST (2001) Antimicrobial activity of certain Indian medicinal plants used in folkloric medicine. Journal of Ethanopharmacology 74(3): 217-220.
25. Aravind G, Debjit B, Duraivel S and Harish G (2013) Traditional and Medicinal Uses of Carica papaya. Journal of Medicinal Plants Studies 1(1): 7-15.

26. Onwuliri FC and Wonang DL (2005) Studies on the combined Antimicrobial action of Ginger (Zingiber officinale L.) and Garlic (Allium sativum L) on some Bacteria. Nigeria J Bot 18: 224-228.

27. Kurtz MB, Heath IB, Marrinan J, Dreikhorn S, Onishi J, et al. (1994) Morphological effects of lipopeptides against Aspergillus fumigatus correlate with activities against (1,3)-beta-D-glucan synthase. Antimicrob Agents Chem 38 (7): 1480-1489.

28. Tsuchiya H, Sato M, Miyazaki T, Fujiwara S, Tanigaki S, et al. (1996) Comparative study on the antibacterial activity of phytochemical flavanones against methicillin resistant Staphylococcus aureus. Journal of Ethnopharmacology 50(1): 27-34.

29. Okwu D and Okwu ME (2004) Chemical composition of Spondias mombin Linn. Plant parts. J Sustain Agric Environ 6(2): 140-147.

30. Stray F (1998) The National Guide to Medicinal Herbs and Plants. Tiger Books International, London. Pp: 1216.

31. Robinson S (1995) Kandungan organic Tumbuhan tinggi diterjemahkan Padnawinata K, Edisike-6 Institute Technology, Bandung, Bandung 193.

32. Marchese A and Shito GC (2001) Resistance patterns lower respiratory tract pathogens in Europe. International Journal of Antimicrobial Agent 16(1): 25-29.

33. Poole (2001) Multidrug efflux pump and antimicrobial resistance in Pseudomonas and related organisms. J Mol Microbiol Biotechnol 3(2):255-264.

34. Kareem KT, Kareem SO, Adeyemo OJ and Egberongbe RK (2010) In-vitro antimicrobial properties of Bridelia ferruginea on some clinical isolates. Agriculture and Biological Journal of North America 1(3): 416-420.

35. Baskaran C, Ratha-bai V, Velu S and Kumaran K (2012) The efficacy of Carica papaya leaf extract on somebacterial and a fungal strain by well diffusion method. Asian Pacific J Tropical 2(S2): S658-S662. 
36. Anibijuwon II, Udeze OA (2009) Antimicrobial Activity of Carica papaya (Paw-paw Leaf) on Some Pathogenic Organisms of Clinical Origin from SouthWestern, Nigeria. Ethno botanical Leaflets 13(7): 850886.

37. Ifesan BOT, Fashakin JF, Ebosele F and Oyerinde SA (2013) Antioxidant and antimicrobial properties of selected plant leaves. European J Med Plants 3(3): 465-473.

38. Uwah AF, Otitoju O, Ndem JI, Peter AI (2013) Chemical composition and antimicrobial activities of adventitious root sap of Musanga cecropioides. Der Pharmacia Lettre 5(2): 13-16.
39. Yahaya A, Ali M and Idris A (2017) Antibacterial Activity and Phytochemical Screening of Carica papaya on some Enteric Bacterial Isolates of Public Health Importance. Greener Journal of Biological Sciences 7(1): 1-7.

40. Orhue PO and Momoh ARM (2013) Antibacterial activities of different solvent extracts of Carica papaya fruit parts on some gram-positive and gram negative organisms. International Journal of Herbs and Pharmacological Research 2(4): 42-47. 